\title{
The Relationshlp Between Abdominal Pain Regions and Speclific Diseases: An Epidemiologic Approach to Clinical Practice
}

\author{
Wari Yamamoto', Hiroshi Kono², Munetaka Maekawa', and Tsuguya Fukul'
}

\begin{abstract}
In onder to evalute the ralationghlp between the patient-identfied regians of abdominal pain and the diseese diagnosis, a prospective study was conducted at Cenced Mecincine Outpatient Clinic, Saga Medical School Hospital. Four hundred eighty-nine outpatients complaining of abdominal pain at the first visit were classifled into 10 groups according to the pain region complained of, l.e., whole abdominal, opigastric, right subcostal, witt subcostal, ripht flank, left flank, periumbllicel, right-lower, mid-lower, and left-lower, the cllnic physlcians and authors in foint-participation assigned the groups through studying the medical records. Compariscons worse made in order to cakulate sensitivity. specificity, and the positive end negathe llkelihood ratios between the pain regions and disease diagnoses.

In generd, the sensitivity of history-taking and physical examinetion is low, but specificty is high in relation to eplgastric pein and gagtroduodenal disoass, right subcostal pain and hepatcblllary diseeses, and mid lower pain and gynecological diseases (above 0.5).

Comperathe anelysis betwean the pain regions complained of by the patient in the initial clinic visit and the medical diagnoses yielded clinically useful infomation as to the efficacy of medlcal history-taking and physical txatrination in the identificatlon of abdominal dlseases.

4 Epiclemiof, $1997 ; 7$; 27-32.
\end{abstract}

abdominal pein, dlegnosis, sensitivity, specificity

Unlike imaging techniques such as ultrasonography. radionuclide scaruing, and conmputed tomography, the value of history taking and physical examinetion, which are not infrequently most impontant part of diagnostic process, has been rarely evaluated by scientific methods. Recently, however, some researchers have made use of epidemiological methods in evaluating these basic clinical skills in clinical practice ${ }^{1-1)}$.

Reganding abdominal pain, textbooks describe that pain in certain abdominal regions ensue in a given certain disease state. However, there are few reports that indicate precisely how we can determine the diseased organ by identifying the pain region. Eskelien et al \%. reported that the most significant predictors of acute appendicitis in putients older than $\mathbf{5 0}$ years of age were tenderness (relative risk $(R R)=39.4$ ), rigidity (RR $=18.8)$, and pain at diagnosis $(R R=11,0)$. The sensitivity of the preoperative clivical decistion in detecting acute appendicitis in the elderly perients was 0.87 , with a specificity of 0.92 . Bounner et al ${ }^{4}$. also reported the sensitivity and specificity of robound tendemess as 0.91 and 0.80 , tenderness in the rightlower quadrant as 0.95 and 0.70 , pein in the rightu-tower quad- rant at presentation as 0.94 and 0.70 , onset of pain in the rightlower quadrant as 0.88 and 0.75 , rigidity as 0.84 and 0.95 , and guarting as 0.87 and 0.76 . In another report, Eskelien et al ${ }^{7}$. foumd that the most efficiem symptoms in tiagnosis of acute small-bowel obstruction were previous abdominal surgery ( $R R=12,1$ ) and type of pain (colic/mintermittent versus steady) ( $R R=24)$. On the other hand, Malone at a reported that the unenhanced computed tomosraphy (CT) had a sensitivity of 0.87 and a specificity of 0.97 for the initial examinetion of patients with suspected acute appendicitis. That is ,the accuracy of unenhanced CT was mostly the same as that of rigidity of pein in the right-lower quatrant in detecting acute appendicitis. Davies et al ". found that ultrasonoggriphy had a sensitivity of 0.96 , a specificity of 0.94 in the acute sbdomen. However. Frase et ald reported that non-specific abdominal pain was associated with persisting pain $(R R=2.22)$ but the sensitivity and specificity of questionnaire assessment were too low to be useful in making a ctinical diagnosis.

To know the probability of the diseased organ from the pain region complained of, this study prospectively evaluated the

Received Setember 30, 1996 ; accepted November 25, 1996.

'Department of General Mecicine and Clinical Epidemiology. Kyoto University Hospital, Kyoto, Japan.

2Department of Genteral Medicine ، Saga Medical School, Saga, Japan.

Address for correspondence : Wari Yamamoto, Department of General Medicine and Cinical Epldemiology, Kyoto University

Hospital, 54 Kawaheractio Shogoin Sakyo-ku Kyoto، 606-01 Japan. 
correlation between the regions of abdominal pain identified by the patients and the diseased organs subsequentiy diagnosed, using such clinical epidemiological characteristics as sensitivity, specificity, and predictive value.

\section{METHODS}

\section{Patients and Doctors}

Subjects were selscted from the patient population ( $n=6021)$ who visited the general medical clinic of Saga Medical School Hospital between April 1, 1988, and March 31, 1989. Four hundred and eighty-nime outpatients complaining of abdnminal pain at the first visit were exartined by 12 general physicians during the study period. The patients" med'ical histories were recorded by each doctor using a form prepened for this study. There was no protocol established for history taking and physical examination, which were done moutinely.

\section{Classification of Abdominal Pain Regions}

The subjects were classified into 10 groups according to the pain region complained of, i.e., whole sbdominal, epigastric, right subcostal, keft subcostal, night flank, left flank, periumbilical, right-kower, mid-lower, and lefi-lower.

\section{Gold Standard}

Three months after the first visit, we evaluated the subjects' metical reconds reganding final diagnosis based on the nesults of blond and urine tests, $X$ ray, and imaging tecturiques such as ultrasonography. Blood and urine tests, $X$ nay, and other inaging tests were not always done in all patients, especially for patients with low probability for significant divease. The number of final diagnosis was made single about abdominal pain.

Gold standards for making diamoses were as follows. Some of the malignant diseases were dingnosed by either biopsy or operation, but others of those were diagnosed by only imaging techniques such as ultrasonography, radionuclide scamning, and computed tomography. Gasuric, duodenal or peptic ulcer, anisakiasis, gastric polyp. and esophageal varices were diagnosed by either barium-swallow gastrointestinal (GI) series or endoscopy. Duodensel diverticula post-gastrectomy syndrome, post-operative intestinal allesion, diverticulinis, and ulcerative colitis were diagmosed by either barium-swallow GI series. barium-enema or endoscopy. The diseases of the liver and biliary tract or pancreatitis were diagnosed by both ultrasonography and blood test. The diseases of the cardiovascular system or pleuritis were diagnosed by ultrasonography, $X$-ray, electrocardiogram (ECG), and blood test. The diseases of the unerus and ovary were diagnosed by ultrasonography, $X$-ray, and blood test by gynecologist. The diseases of the urinary tract were diagnosed by ultrasonography, intravenous pyelogram, and urine test. According to gastritis, acute enteritis, gas pain, irritable bowel syndrome, upper respiralory infoction, and psy- chological problem, the decision of the clinicians based on the results of blood and urite tests, $X$ ray, and imaging wechniques is the gold standard for diagnosis. Neuralgia and musculoskeletal diseases without specific skin lesions were re-delermined on the bases of history and folkw-up findings.

\section{Analysis}

We calculated the sensitivity, spectficity, and likelihood ratios of each abdominal pain region with respect to organ disease. Bivariate analysis about the relationship between the patient-identified regions of abdominal pain and the disease diagnosis was calculated using chi-square test and differences in subject characteristics were tanalyzed by one way layout analysis of variano(ANOVA). Significance levels were set to 0.05. The JUMP statistical package (SAS Inc., USA) was utilized for the analysis.

\section{RESULTS}

Twelve physicians (mean post-patuluate year, 63, range, 2 to 19 ) saw a toral of 489 patients with shdominal pain in a 1-year period( $8.1 \%$ of patients who visited the oneral medical climic).

Patient characteristics were as follows: men, 214; women, 275; mean age \pm standand deviation. 44.4 \pm 16.4; range of age, 16 to 89. Difference of mesn age of subgroups of pain region was not significant for one way layout ANOVA ( $\mathrm{P}=0.87$ ). However, sex difference of distribution of subquoups of pain region, epigasuric pain, was significant for chi-square (P-0.01).

The number of subjects scoording to pain region as follows: whole abdominal pain, 61; epigastric,232; right subcostal, 45; left subcostal, 5; right flank, 13; left flank, 18; periurnbilical,7; right-lower, 30; mid-lower, 49; and left-lower, 29. Distribution with respect to the regions of abdominal pain and final diagnoses was shown in Figure 1.

Final diagnoses were as follows: gastroduodenal disease, 39.1\%; intestind disease, $24.5 \%$; hepatobiliary disease. $7.6 \%$; urinary tract disease, $4.1 \%$; gynecological disease, $3.9 \%$; musculoskeletal disese, 3.5\%; respiratory disesse, $0.8 \%$; skin $\mathrm{dj}$ sease, $0.8 \%$; pancreatic disease, $0.6 \%$; cardiovascular disease, $0.6 \%$; others $14.4 \%$. Distribution of specific tisease in these categories was shown in Table 1.

With respect to the etinlogy ahourt sbdominal pain, the mumber of subjects who had a inflammarion was 156, functional disorder 78, ulcer 63, normal findings 55, stme of organs 29 . viral or becterial infection 21, malignan disease 16, psychological problem 12, post-operative disonder 5, unknown origin 2 , and others 52.

Table 2 shows the sensitivity, specificity, and positive and negative likelihood ratios of specific pein regions for diseases of the stomach and duodenum, intestine, liver and biliary tract. utenus and ovary, and urinary trext. Likelihood ratios are an alternative way of describing the perfomance of a diagnostic 
test. They summarize the same kind of information es sensitivity and pecificity and can be used to calculare the probability of disease after a positive or negative test ".

Right-subcostal pain related to hepatobiliary diseases, periumbilical pain related to intestinal diseases, and mid-lower pain related to gynecological diseases had high positive likelihood ratios. On the ocher hand, epigastric pain related to gastrochuodenal diseases, and mid-lower pain related to gynecological diseases had low negative likelihood ratios.

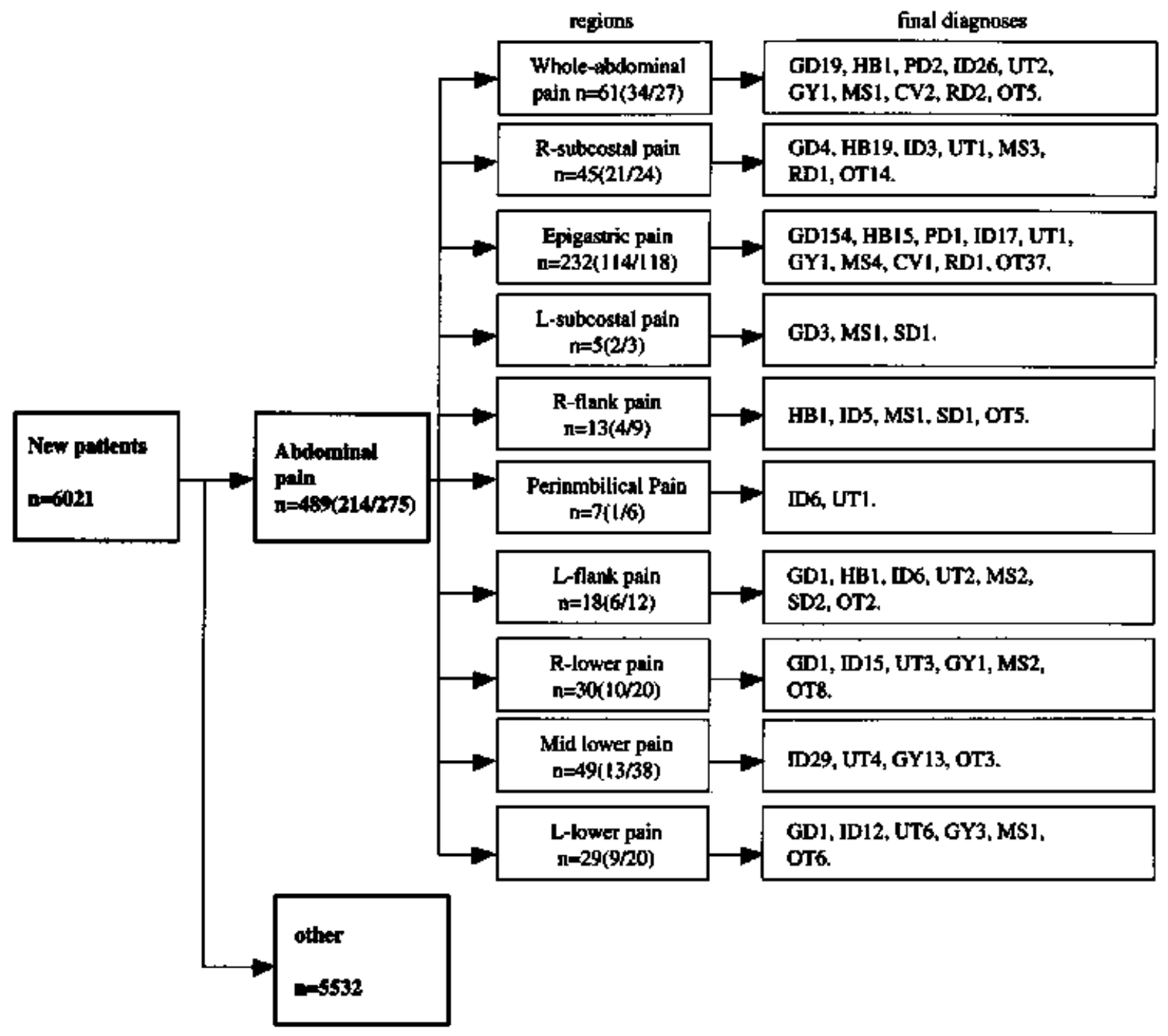

GD: pastroduodenal disease, HB: hepatobilisy disease. PD: pancreatic disease, ID: intestinal disease UT: urinary tract disease, GY: gynecological dísease, MS: muscloskeleial disese, RD: respiratory disease, CV: cardiovascular disense, SD; stin disease, OT: other (1) means number of maleffemale

Figwe 1. Patient distribution with respect to the regions of abdominal pain and final diugnoses. 
Twide 1. Final diagnoses in patients presenting with abdominal pain at the general metical clinic of Saga Medical School Hospital.

\begin{tabular}{|c|c|c|c|}
\hline $\begin{array}{l}\text { Diseases of the tophagus, stomach and } \\
\text { duodentum }\end{array}$ & 190 & $\begin{array}{l}\text { Gastritis } \\
\text { Gastric ulcer } \\
\text { Duodenal ulcer } \\
\text { Peptic nlctr' } \\
\text { Gastric cancer } \\
\text { Duodengl diverticuli } \\
\text { Anisekiesis } \\
\text { Gastric polyp } \\
\text { Post-gastrectomy syndrome } \\
\text { Esophageal verices }\end{array}$ & $\begin{array}{r}111 \\
37 \\
19 \\
7 \\
6 \\
3 \\
3 \\
2 \\
1 \\
1\end{array}$ \\
\hline Diseases of the liver and biliary tract & 37 & $\begin{array}{l}\text { Gall stone } \\
\text { Hepatitis } \\
\text { Liver turnor } \\
\text { Infection of biliary tract } \\
\text { Gallbladder caucer } \\
\text { Hepacosplenomegaly }\end{array}$ & $\begin{array}{r}17 \\
8 \\
5 \\
3 \\
2 \\
2\end{array}$ \\
\hline Diseases of the pancreas & 3 & $\begin{array}{l}\text { Pancreatic camcer } \\
\text { Pancreatitis }\end{array}$ & $\begin{array}{l}2 \\
1\end{array}$ \\
\hline Diseases of the intestine & 119 & $\begin{array}{l}\text { Constipation (functional) } \\
\text { Acute enteritis } \\
\text { Gas pain } \\
\text { Irritable bowel syndrome } \\
\text { Colon cancer } \\
\text { Diverticulitis } \\
\text { Ulcerative colitis } \\
\text { Appendicitis } \\
\text { Hemorrboid } \\
\text { Hemia }\end{array}$ & $\begin{array}{r}33 \\
29 \\
29 \\
16 \\
5 \\
3 \\
1 \\
1 \\
1 \\
1\end{array}$ \\
\hline Diseases of the urinary tract & 20 & $\begin{array}{l}\text { Stone of the urinary tract } \\
\text { Infection of the urinary tract } \\
\text { Prostatitis }\end{array}$ & $\begin{array}{r}12 \\
7 \\
1\end{array}$ \\
\hline Diseases of the uttens and ovary & 19 & $\begin{array}{l}\text { Pelvic isflammatory disease } \\
\text { Gynecological disease } \\
\text { Menstruational pain } \\
\text { Myoma uteri } \\
\text { Uterine cancer }\end{array}$ & $\begin{array}{l}7 \\
5 \\
4 \\
2 \\
1\end{array}$ \\
\hline Diseases of the muscle and bout & 17 & $\begin{array}{l}\text { Muscular pain } \\
\text { Neuralgia }\end{array}$ & $\begin{array}{r}15 \\
2\end{array}$ \\
\hline Diseases of the cardiovascular system & 3 & $\begin{array}{l}\text { Congestive beart failure } \\
\text { Aortic aneurysm } \\
\text { Myocardial infarction }\end{array}$ & $\begin{array}{l}1 \\
1 \\
1\end{array}$ \\
\hline Diseases of the respiratory system & 4 & $\begin{array}{l}\text { Upper respiratory infection } \\
\text { Pleuritis }\end{array}$ & $\begin{array}{l}3 \\
\mathbf{I}\end{array}$ \\
\hline Diserses of the skin & 4 & $\begin{array}{l}\text { Herpes zoster } \\
\text { Contract dematitis }\end{array}$ & $\begin{array}{l}3 \\
1\end{array}$ \\
\hline Others & 73 & $\begin{array}{l}\text { No abnomality found } \\
\text { Psychological problem } \\
\text { Post-operative intestinal whesion } \\
\text { Unknown }\end{array}$ & $\begin{array}{r}55 \\
12 \\
4 \\
2\end{array}$ \\
\hline
\end{tabular}


Table 2. Sensitivity, spexificity, and the positive and negative likelihood ratio between the pain regjions and disease diagnoses.

\begin{tabular}{|c|c|c|c|c|}
\hline \multicolumn{5}{|c|}{ Diseases of the esophagus, stomech and duodenum. } \\
\hline & Sensitivity & Specificity & $L R+(95 \% C)$ & LR-(95\%CI) \\
\hline Epigestric pain & 0.84 & 0.75 & $3.30(2.06-5.29)^{*}$ & $0.21(0.13-0.34)^{*}$ \\
\hline R-subcostal pain & 0.02 & 0.87 & $0.16(0.06-0.45)^{*}$ & $1.13(0.40-3.21)$ \\
\hline Whole-abdominal pain & 0.10 & 0.86 & $0.76(0.43-1.35)$ & $1.04(0.58-1.85)$ \\
\hline \multicolumn{5}{|c|}{ Diseases of the liver and biliary tract } \\
\hline & Sensitivity & Specificity & $L R+(95 \%$ Cl) & LR-(95\%(I) \\
\hline Epigastric pain & 0.41 & 0.52 & $0.84(0.42-1.66)$ & $1.14\{0.58-2.25\}$ \\
\hline R-subcostal pain & 0.51 & 0.94 & $8.93(4.19-19.0)^{*}$ & $0.52(0.24-1.11)$ \\
\hline \multicolumn{5}{|c|}{ Diseases of the intestine } \\
\hline & Sensitivity & Specificity & $L R+(95 \% C])$ & LR- $\{95 \%$ CI $\}$ \\
\hline R-lower pain & 0.13 & 0.96 & $3.11(1.47-6.57)^{*}$ & $0.91(0.43-1.92)$ \\
\hline Mid-lower pain & 0.16 & 0.89 & $1.41(0.78-2.53)$ & $0.95(0.53-1.71)$ \\
\hline L-lower pain & 0.10 & 0.95 & $2.19(1.01-4.73)^{*}$ & $0.94(0.44-2.03)$ \\
\hline Periumbilical pain & 0.05 & 0.99 & IB. $66\{2.22-156.7\}^{*}$ & $0.95(0.11-7.97)$ \\
\hline \multicolumn{5}{|c|}{ Diseases of the urinary tract } \\
\hline & Sensitivity & Specificity & L.R $+(95 \% C \mathrm{C})$ & LR-(95\&CI) \\
\hline R or L-lower pain & 0.45 & 0.89 & $4.22(1.67-10.68)^{*}$ & $0.62(0.24-1.57)$ \\
\hline Mid-lower pain & 0.20 & 0.90 & $2.08(0.67-6.49)$ & $0.88(0.28-2.75)$ \\
\hline \multicolumn{5}{|c|}{ Diseases of the uttrus and ovary } \\
\hline & Sensitivity & Specificity & $L R+(95 \%(I)$ & LR-(95\%Cl) \\
\hline Mid-lower pain & 0.68 & 0.92 & $8.93(3.20-24.9\}^{*}$ & $0.34(0.12-0.95)^{*}$ \\
\hline
\end{tabular}

LR+: Positive liketihood ratio. LR:- Negative jikelihood ratio. *:p<0.05

\section{Discussion}

In general, the sensitivity of history taking and physical examination was low and the specificity high. Howewer, the sensitivity of epigastric pain related to gastroduodenal diseases, right subcostal pain related to hepatobiliary diseases, and midlower pain related to gynecological diseases was relatively high (above 0.5 ) in this study. Men significantly complain of epigastric pain more frequent rate than that of women. On the other hand, women relatively complain of lower abdominal pain more frequent rate than that of men. Therefore, the rate of men's epigastric pain merely might be high in appearance.

Because of the high sensitivity (0.84) of epigastric pain in terms of gastoroduodenal diseases, absence of epigastric pain is useful to nule out gastroduodenal diseases.

On the other hand, high specificity (above 0.92) of periumbilical pain makes it possibk to confidendy diagnose intestinal disease. The same is true for right subcostal pain in hepalobiliary disenses and for mid-kower pain in gynecological disenses.

There were several opportunicies for bias to affect the results of our standy. Selection bias occurs when comparisons are made between groups of paxients that differ in ways, other than the main factors under study, that affect the outcome of the study. Group of patients often differ in many way- age. sex. severity of disease, presence of the other disease, and the care they receive. This study was conducted ar a general medical climic in a university hospital. Therefore, it is most likely that there is a limited generalibility of our results. In ususl practice rost clinicians interview the patient and perform a general physical examination prior to specifically evaluating the abdomen. Verification bias oxcuss when the study population is constrained to include only selected patients whose severe disease status is verified, and when the selection for the verification lest not random ${ }^{10}$. Such expectation bias may improve or worsen test operating characteristics by increasing sensitivity or decreasing specificity. Since our study was performed under usual clinical circumstances, we did not study the effect of expectation bias during the history-taking and physical examination. Because this study took place during active nottine work perinds, perticipating physicians" maximum clinical performance may not have been reflected.

In summary, we found that the patient's history of some abdominal pain was highly predictive of the presence or absence of the diseases. Comparative analysis between the pain regions complained by the patient in the initial clinical visit and the medical diagnoses yjelded clinically useful information as to the efficacy of medical history-taking and physical examination in the identification of abdominal diseases. 


\section{REFIRENCES}

1. Feinstein AR. Clinical Epidemiology. The Anchitecture of Clinical Research. Philadelphia: WB Saunders Co. 1985.

2. Fletcher RH, Fletcher SW, Wagner EH. Clinical Epidemiology. The Essentials. 3rd ed. Baltimore: Williams \& Wilkins, 1996.

3. Sackett DL, Hayenes RB, Tugwell P. Clinica] Epidemialogy. A Basic Science For Clinical Medicine. Boston: Little Brown and Co, 1991 .

4. Fukui $T$. Relative contribution of history-talking, physical examination, and stat laboratory test to diagnosis in chest pein patiems. Jpn. J. Public Healh 1990 ; 37 :569-575.

5. Eskelinen M, Ikonen J, Lipponen P.The vilue of historytaking, physical examination, and computer assistance in the diagnosis of acute appendicitis in patients more than 50 years old Scand J Gastroenterol, $1995 ; 30: 349-355$.

6. Bohner $H$, Yang Q, Franke $K$, Ohmann C. Significance of anannesis and climical findings for diagnosis of acute appendicitis. Acute Abdominal Pain Study Group. Z Gastroenterol. 1994 ; 32: 579-583.

7. Eskelinen M, Ikonen J, Lipponen P. Contributions of history-taking, physical examination, and computer assistance to diagnosis of acute small-bowel obstruction. A prospective study of 1333 parients with acule abdominal pein. Scand J Gastroenterol. 1994 ; 29 : 715-721.

8. Malone AJ Jr, Wolf CR, Malmed AS, Melliere BF. Diagnosis of acute appendicitis: value of unenhanced CT. Am J Roentgenol. 1993 ; 160 : 763-766.

9. Fruser SC, Sinith K, Agarwal M, Bares T. Psychological screening for non-specific abrominal pain. Br J Surg. $1992 ; 79$ : 1369-1371.

10. Davies AF, Mastorakou I, Cobb R, Rogers C. Lindsell D, Mortensen NJ. Ulurasonography in the acute abdornen. Br J Surg. 1991 ; 78 : 1178-1180.

11. Greenes RA, Begg CB. Assessment of diagnostic technologies: methodology for unbiased estimation from samples of selectively verified patients. Invest Radiol 1985 : 20 : 751-756. 